\title{
EESTI KEELE OTSTARBELAUSEST
}

\author{
HELEN PLADO
}

\section{Sissejuhatus}

O tstarbelause on üks põhjuse-tagajärje suhet väljendavatest adverbiaallausetest, mis on siiani eesti keeles üsna vähe käsitlemist leidnud. Samal ajal on otstarbelause mitmes mõttes huvipakkuv. Ühelt poolt on otstarbelausega liitlause põhjuse-tagajärje suhet edasi andvate põimlausete hulgas erandlik ses mõttes, et otstarbelause väljendab ühtaegu nii pealause sündmuse põhjust kui ka tagajärge; teisalt aga pakub huvi otstarbelause verbivormi valik: millal kasutatakse $d a$-infinitiivset ja millal konditsionaalset öeldisverbi. Käesolev artikkel annab eesti keele otstarbelausest ülevaate tüpoloogilisel taustal.

Otstarbelauset sisaldav liitlause seob omavahel kaks sündmust või olukorda, millest üks (pealausega edasi antu) sooritatakse eesmärgiga, et see tooks kaasa teise sündmuse või olukorra (kõrvallausega edasi antu) (Cristofaro 2003: 157), s.t otstarbelause väljendab pealausega tähistatud sündmuse otstarvet (EKG II: 310) või eesmärki. Tüüpiliselt väljendavad otstarbelaused tahtliku tegevuse oodatavat tagajärge, Sonia Cristofaro on nimetanud kõige tüüpilisemaks otstarbelauseid, mis seostuvad liikumisverbiga (2003: 157). Näide 1 on ses mõttes tüüpiline: kõrvallausega väljendatakse pealause liikumissündmuse $A$ läks välja otstarvet või eesmärki, milleks on väikese jalutuskäigu tegemine. Näite 1 puhul on pealause ja kõrvallause tegija sama, kuid alati ei pruugi see nii olla (näide 2). Seejuures ei ole ka kindel, kas pealause tegijal on kontroll kõrvallausega väljendatud sündmuse realiseerimise üle.

(1) A läks välja, et teha väike jalutuskäik järve äärde. (ILU1990)

(2) Pidasime pöialt, et „Kalevi” mäng õigel ajal läbi saaks. (AJA1990)

Et otstarbelause olukorra või sündmuse realiseerimine on võrreldes pealause olukorra või sündmusega tulevikuline, jääb lahtiseks, kas otstarbelausega edasi antud kavatsetav sündmus ka tegelikult aset leiab. Seetõttu on ka mõistetav, miks paljudes keeltes, sh eesti keeles kasutatakse otstarbelauses hüpoteetilisust väljendavaid verbivorme (nt subjunktiivi, konditsionaali). Eesti keele otstarbelause predikaat võib olla kas tingivas kõneviisis (näide 2) või juhul kui pea- ja kõrvallause tegevussubjekt on sama, ka $d a$-infinitiivis (näide 1) (EKG II: 310). Artikli üheks eesmärgiks ongi välja selgitada, mis tingimustel kumbagi vormi kasutatakse ning kas EKG esitatud tingimus $d a$ infinitiivi kasutamiseks peab paika. Põhjalikumalt käsitletakse otstarbelause predikaadi vormi peatükis 5 .

Eesti keeles on otstarbelauseks üldalistava konjunktsiooniga et markeeritud kõrvallause, fakultatiivseteks korrelaatideks on selleks, seejaoks, selle jaoks, selle tarvis, sellel $\sim$ sel otstarbel, sellel $\sim$ sel eesmärgil, selleks otstarbeks 
jmt. Korrelaat selleks võib kuuluda ka kõrvallausesse ning moodustada sidesõnaga et ühtse korrelaatsidendi (EKG II: 310).

Artikkel tutvustab eesti keele otstarbelausete liike ning annab seejärel ülevaate eesti keele otstarbelausete seostest teiste adverbiaal- (täpsemalt põhjus- ja tagajärjelausega) ja komplementlausetega. Seejärel näidatakse, kas ka otstarbelausete hulgas saab eristada samasuguseid funktsionaalseid tüüpe (lisaks sisutasandi kõrvallauseile ka episteemilisi ja konversatsioonilisi kõrvallauseid), nagu näiteks põhjus-, tingimus- ja mööndlausete puhul (vt Plado 2008; Plado, Lindström 2012). Põhjalikumalt käsitleb artikkel $d a$-infinitiivse ja konditsionaalse öeldisverbiga otstarbelausete kasutust.

Artikkel põhineb Tartu Ülikooli kirjakeele korpuse 1990. aastate allkorpuses leiduvatel otstarbelausetel. Vaatluse alla olen võtnud nii ilukirjandus- kui ka ajakirjandustekstidest (näitelausetes vastavalt ILU1990 ja AJA1990) pärit laused ja ma käsitlen neid koos. Ühtekokku leidsin 1455 otstarbelauset. Nende hulgast jätan analüüsist välja kolm lauset, kus on kas kõrvallause jäänud poolikuks või kus puudub öeldisverb. Otstarbelausena käsitlen ka juhte, kus pea- ja otstarbelause on vormistatud eraldi ortograafiliste lausetena.

\section{Eesti keele otstarbelause liigid}

Kui tüpoloogias käsitletakse otstarbelausetena enamasti kõrvallauseid, mis annavad edasi pealause tahtliku tegevuse otstarvet (vt Cristofaro 2003; Schmidtke-Bode 2009, 2010), siis meie keeleuurimises ei seostata otstarbelauset vaid pealause tahtliku tegevusega. EKG II (1993: 310) eristabki kaht tüüpi otstarbelauseid.

1. Need, mis väljendavad otstarvet kui taotletavat (soovitavat) tulemust. Nende lausete puhul väljendab pealause predikaat tegevussubjekti kontrollitavat tahtlikku tegevust või seisundit (näide 3 ).

(3) Juku õpib selleks, et targemaks saada.

2. Need, millega väljendatud otstarve ei ole mitte tahtliku tegevusega taotletav tulemus, vaid funktsioon, mille täitmiseks on keegi või miski vajalik/ mittevajalik või sobiv/sobimatu (näide 4).

(4) Juhan oli küllalt taibukas, et juhust kasutada.

Lisaks neile ilmneb keelematerjalist veel üks tüüp, mida väljendatakse küll otstarbelausekujulise osalausega, kuid mis ei anna otseselt edasi pealause sündmuse otstarvet, vaid väljendab enamasti hoopis ajalist järgnevust. Siiski võib ka selliste lausete puhul näha kõrvallauset edasi andmas pealause sündmuse kujuteldavat tagajärge: pealause sündmus toimub justkui vaid selleks, et saaks toimuda kõrvallausega edasiantud järgnev sündmus. Näiteks lause 5 kirjeldab vormelisõitu. Vaevalt et vormelijuhi eesmärgiks on paarisaja meetri pärast rajalt välja sõita, nii et siin ei kirjeldata kõrvallausega mitte pealause sündmuse otstarvet, vaid antakse edasi kahe osalause sündmuste ajalist järgnevust. Siiski võib ka siin näha kõrvallausega edasiantut kui pealause sündmuse kujuteldavat tagajärge. Samal ajal on ka juhtumeid, kus kõrvallausega 
väljendatud kaudne otstarve on selgemini nähtav (näide 6). Enamasti kuulub seda tüüpi kõrvallausesse ajalist järgnevust väljendav adverb (nt seejärel, siis, nagu näites 6) või ka muu ajamäärus (nagu näites 7). Kõikides seda tüüpi lausetes, mis 1990. aastate korpuses esinesid, kattub kõrvallause subjekt pealause tegevussubjektiga ning kasutatud on $d a$-infinitiivset predikaati. Seda tüüpi otstarbelauseid on peetud lähedasteks tagajärjelausetele (vt täpsemalt alajaotisest 3.2).

(5) Temagi jätkas, kuid vaid selleks, et paarisaja meetri pärast lõplikult liiva söösta. (AJA1990)

(6) Ministeerium on valmis võtma need ettevõtted... tagasi oma haldusse, et seejärel erinevate ettevõtete omapäraga veelgi täpsemalt tutvuda. (AJA1990)

(7) Kui koostöö katkes, lagunes üsna peatselt ka Smokie, et 1985. aastal uuesti kokku tulla. (AJA1990)

Edaspidi nimetan neid tüüpe vastavalt I, II ja III tüüpi otstarbelauseteks.

Analüüsimaterjalis esineb enim I tüüpi otstarbelauseid, s.t neid, kus otstarbelause väljendab tahtliku tegevuse soovitud tagajärge (939 lauset ehk $64,7 \%$ ), neile järgnevad esinemissageduse poolest II tüüpi otstarbelaused (461 lauset ehk 31,7 \%) ning vähim esineb III tüüpi otstarbelauseid (52 lauset ehk $3,6 \%)$.

Kuigi otstarbelause on nii semantiliste kui ka morfosüntaktiliste joonte poolest selgelt eristuv adverbiaallause tüüp, on see mitme omaduse poolest sarnane teiste kõrvallausetega. Järgnevalt tutvustangi lähemalt otstarbelause seoseid teiste adverbiaallausetega ja komplementlausega.

\section{Otstarbelausete seos teiste kõrvallausetega}

\subsection{Otstarbelause seos komplementlausega}

Komplementlause ja adverbiaallause piir ei ole üheselt selge. Kuigi komplementlause on seotud ja adverbiaallause vaba laiend, ${ }^{1}$ on nende vahel struktuurilisi sarnasusi, mis ähmastavad nende lausetüüpide eristust (Erelt 2004: 402-403). Seetõttu ei ole üllatav, et otstarbelauseid ongi eriti lähedaseks peetud komplementlausetele, ${ }^{2}$ nendel kahel lausetüübil on nii semantilisi, morfosüntaktilisi kui ka diskursusepragmaatilisi ühisjooni.

Semantiliselt on otstarbelause lähedane neile komplementlauseile, mis laiendavad soove väljendavaid verbe. Mõlemal juhul sisaldub lauseis ühe osalise soov teatud olukorra või sündmuse realiseerumiseks. Nii otstarbe- kui ka komplementlausega väljendatud olukorra või sündmuse realiseerumist peetakse (pealause sündmuse või olukorraga võrreldes) tulevikus võimalikuks. (Cristofaro 2003: 157-158).

Komplement- ja otstarbelause sarnasus väljendub ka vormiliselt. Tõenäoliselt just sellest, et mõlema kõrvallause sündmuse või olukorra realiseerumine

${ }^{1}$ Tõsi, on olemas ka seotud adverbiaale.

${ }^{2}$ Karsten Schmidtke-Bode (2009: 158) tüpoloogilise uurimuse keelevalimi hulgas oli $77,5 \%$ keeltest otstarbelausetel ning komplementlausetel üks või mitu kokkulangevat morfosüntaktilist tunnust. 
tulevikus on lahtine, tuleneb see, et vaadeldavates kõrvallausetes saab kasutada samu verbivorme, s.t nii konditsionaali (näide 8 ja 8') kui ka da-infinitiivi (näide 9 ja 9'). Siiski võib komplementlauses esineda muidki verbivorme.

(8) Siis pidi kähku tünni juurde jooksma, et kallis kraam raisku ei läheks. (ILU1990) (Otstarbelause.)

(8') Soovisime, et kallis kraam raisku ei läheks. (Komplementlause.)

(9) Et asjasse selgust tuua, võtsin ette käigu EV kaubandusministeeriumi. (AJA1990) (Otstarbelause.)

(9') Ta taipas, kuidas asjasse selgust tuua. (Komplementlause.)

Lisaks kasutatakse komplement- ja otstarbelauses sama alistavat sidendit et. Kokkulangevus pole juhuslik, vaid komplementlause konjunktsioon on sagedaseks otstarbemarkeri allikaks (Heine, Kuteva 2002: 91). Ka Rudolf Karelson (1959: 103) on näidanud, et et-konjunktsiooni on komplementlause markerina kasutatud varem kui otstarbelause markerina.

\subsection{Otstarbelause seos teiste adverbiaallausetega}

Teistest adverbiaallausetest on otstarbelause enim seotud põhjus- ja tagajärjelausega. Sarnasuse kord põhjus-, kord tagajärjelausega tingib tõenäoliselt see, et otstarbelause korral on pea- ja kõrvallause sündmuse vahel kahetine põhjuse-tagajärje suhe: otstarbelause annab ühtaegu edasi nii põhjust kui ka tagajärge, s.t ühelt poolt väljendab otstarbelause pealausega kirjeldatud tegevuse põhjust, kuid teiselt poolt ka pealause tegevuse/sündmuse oodatavat tagajärge, s.t tagajärg on kõnehetkel irreaalne, me ei tea, kas see sündmus ka tegelikult aset leiab (vt ka Itkonen 2001: 336). Näites 10 on meeste saalist välja ajamise soovpõhjuseks see, et naised julgeksid rääkida; samas aga on meeste saalist väljaajamise arvatavaks tagajärjeks see, et naised julgevad rääkida.

(10) Ajasin kõik mehed saalist välja, et naised julgeksid rääkida. (AJA1990)

Et I tüüpi otstarbelaused annavad edasi pealausega väljendatud tegevuse (soov)põhjust, on otstarbelaused lähedased põhjuslausetele (EKG II: 310). Lisaks on otstarbelauses kasutatav konjunktsioon et ka üks põhjuslause konjunktsioonidest, ning kui põhjuslause väljendab põhjust, mis ei ole kõnehetkeks realiseerunud, võib selles kasutada samu verbivorme kui otstarbelauseski. Sellistel juhtudel võib otstarbelause mõnikord põhjuslausega asendadagi (vrd näiteid 11 ja 11'). Kõrvallause liigi määrab sel juhul pealauses asuv korrelaat (selleks pro sellepärast).

(11) Siin kirjutan vist kõige enam selleks, et tutvustada üht arusaama, mida pean oluliseks. (ILU1990) (Otstarbelause.)

(11') Siin kirjutan vist kõige enam sellepärast, et tutvustada üht arusaama, mida pean oluliseks. (Põhjuslause.)

Põhjus- ja otstarbelause lähedus ei ole eesti keele eripära, vaid nende kahe adverbiaallause struktuuride sarnasust leiab üle kogu maailma (SchmidtkeBode 2009: 154), paljudes keeltes on need adverbiaallaused lausa üksteisest vormiliselt eristamatud (Thompson, Longacre 1985: 185). 
Tagajärjelausega ei ole eesti keele otstarbelause vormiline sarnasus nii suur kui komplement- ja põhjuslausega. Tagajärjelause konjunktsiooniks on kujunenud nii et. Et tagajärjelause puhul on teada, kas sellega esitatud sündmus/olukord on aset leidnud, ei ole selles kõrvallauses hüpoteetilisust väljendavate verbivormide kasutamise kohustust, s.t eesti keele tagajärjelauses on öeldisverb peamiselt indikatiivis. Karsten Schmidtke-Bode (2009: 152) sõnul ongi peamiseks otstarbe- ja tagajärjelause erinevuseks see, kas alistatud lausega edasi antud sündmus või olukord on tegelikult ka pealause sündmuse toimumisest põhjustatud (tagajärg, näide 12) või mitte (otstarve, näide 12'). See kehtib aga eelkõige nende keelte puhul, kus otstarbe- ja tagajärjelause markeriks on täpselt sama konjunktsioon ning neid kaht adverbiaallauset eristab vaid see, et otstarbelause finiitne predikaat on markeeritud kui hüpoteetiline (s.t konditsionaali, subjunktiivi vmt abil). ${ }^{3}$ Schmidtke-Bode käsitlus kehtib enamasti eesti keele I tüüpi otstarbelausete puhul.

(12) Joonas paiskas paar rukkivihku kõrvale, nii et hele päevavalgus öökambrisse pääses. (ILU1990)

(12') Joonas paiskas paar rukkivihku kõrvale, et hele päevavalgus öökambrisse pääseks.

Tagajärjelausetega on suurem semantiline ühisosa sellistel II tüüpi otstarbelausetel, mis annavad edasi funktsiooni, mille täitmiseks on keegi/miski sobiv/sobimatu. Tõenäoliselt on läheduse põhjuseks ühelt poolt selliste otstarbelausete madal hüpoteetilisus, s.t on teada, kas kõrvallausega edasi antu toimub või ei toimu / toimus või ei toimunud, kuid teiselt poolt tingib sarnasuse ka see, et seda tüüpi lausete puhul ei ole otstarbelausetega liitlausetele omast põhjuse-tagajärje suhte kahetisust, vaid kõrvallause väljendab alati pealausega edasi antud sündmuse või olukorra tagajärge. Näites 13 on teada, et kõrvallausega edasi antu on toimunud, s.t süsteemi on hoitud ka keerulistel aegadel. Samas ei tulene kõrvallause madal hüpoteetilisus ainult pealause minevikulisest ajavormist: nt lause 14 puhul on samuti selge, et kõrvallausega väljendatu ei toimu. Sellistel juhtudel on otstarbelause kergelt asendatav tagajärjelausega, vrd vastavalt näiteid 13' ja 14'.

(13) Meil on olnud piisavalt energiat ja võimu, et hoida seda süsteemi ka keerulistel aegadel. (AJA1990)

(13') Meil on olnud piisavalt energiat ja võimu, nii et oleme saanud hoida seda süsteemi ka keerulistel aegadel.

(14) Praegu ootab ja nõuab vastuvõtmist suur hulk seadusi, meil ei jätku aga inimesi ja aega, et seda teha. (AJA1990)

(14') Praegu ootab ja nõuab vastuvõtmist suur hulk seadusi, meil ei jätku aga inimesi ja aega, nii et me ei saa seda teha.

Tagajärjelauseile veelgi lähedasemad on III tüüpi otstarbelaused. Seda tüüpi kõrvallauseid peab Kirsi Höglund (2006: 56) lausa tagajärjelausete hulka kuuluvaiks, kuid Schmidtke-Bode (2009: 153) otstarbe- ja tagajärjelausete vahelisse alasse jäävaiks; nimelt väidab Schmidtke-Bode (2009: 153), et selli-

\footnotetext{
${ }^{3} \mathrm{Nii}$ on näiteks inglise keeles so that-osalausete puhul.
} 
sed inglise keele otstarbelaused võivad väljendada ka tagajärge (näide 15). Ka eesti keele lauses 16 on see, et taksojuht peab taas rivi lõpust ootamist alustama, lühikese otsa tegemise tagajärg. Samal ajal ei ole aga nende lausete puhul pea- ja kõrvallause sündmuse põhjuse-tagajärje suhe nii selge kui tavapäraste tagajärjelausete korral ning sugugi mitte kõikide seda tüüpi lausete puhul ei anna kõrvallause edasi pealause sündmuse tagajärge.

(15) I went around the corner, just to run into my old friend Jack. 'Läksin ümber nurga vaid selleks, et kokku põrgata oma vana sõbra Jackiga'

(16) Pika taksoderivi ära seisnud juht lihtsalt ei hakka lühikest otsa tegema, et taas rivi lõpust alustada. (AJA1990)

Lisaks kolmele põhitüübile eristuvad otstarbelausete hulgas ka eri funktsionaalsed tüübid.

\section{Otstarbelause funktsionaalsed tüübid}

Eve Sweetser (1990) jagab adverbiaallaused kolmeks: sisutasandi-, episteemilised ja kõneaktiadverbiaallaused (eesti keele kohta vt põhjalikumalt Plado 2008). Sisutasandi adverbiaallaused on tüüpilised adverbiaallaused, s.t nt põhjuslausetest need, mis annavad edasi pealausega väljendatud sündmuse põhjust: nt Mats ei suuda kookide söömisest loobuda, sest need on nii maitsvad on kookide maitsvus põhjuseks, miks ei suuda Mats nende söömisest loobuda. Episteemiliste adverbiaallausete puhul on põhjuse-tagajärje ahel sisutasandi adverbiaallausetega võrreldes teistpidi pööratud ning kõrval- ja pealause vahele on tõusnud järeldussuhe: nt lauses Koogid peavad olema väga maitsvad, sest Mats ei suuda nende söömisest loobuda väljendab pealause põhjust (kookide maitsvus) ning kõrvallause tagajärge. Kõneaktiadverbiaallaused ei ole seotud mitte pealause ega ka eelneva tekstiga, vaid kõneaktiga, mida pealause sooritab (Thompson, Longacre 1985: 203): nt lauses Kuna sul peab kõht väga tühi olema, siis külmkapis on lasanjet ei ole see, et külmkapis on lasanjet, põhjustatud sellest, et vestluspartneril on kõht tühi, vaid kõneakti sooritamine (praeguse näite puhul lasanje pakkumine) on põhjustatud sellest, et kõneleja arvates on vestluspartneril kõht tõenäoliselt väga tühi. Mõnikord (nt Dancygier 2006; Dancygier, Sweetser 2006) on eraldi tüübina käsitletud ka metakeelseid adverbiaallauseid, mille abil kõneleja kommenteerib pealause sõnavalikut, nt: Ikka tuli ette kaklusi, pigem küll sõnavahetusi, sest ma polnud teab mis suur riiukukk. Plado (2008) on kõneakti- ja metakeelelisi adverbiaallauseid käsitlenud koos konversatsiooniliste adverbiaallausetena; sama käsitlust järgitakse siingi. Ka otstarbelausete hulgas esineb kõiki kolme liiki kõrvallauseid.

Sisutasandi otstarbelaused annavad edasi pealausega väljendatud sündmuse soovpõhjust ehk otstarvet, s.t kõrvallause väljendab põhjust ja pealause tagajärge, nt lauses 17 on millegi küsimise soov põhjuseks ning selle soovi tagajärjeks on auto peatamine.

(17) Peatasin auto, et midagi küsida. (AJA1990) 
Episteemilise tasandi otstarbelauseid analüüsitud materjali hulgas ei leidunud. Siiski ei ole need eesti keeles võimatud, nt lause 17' puhul on tegemist tüüpilise episteemilise adverbiaallausega. Põhjuse-tagajärje suhe on siin lausega 17 võrreldes vastupidine: pealause väljendab põhjust ja kõrvallause tagajärge. Lisaks valitseb siin osalausete sündmuste vahel järeldussuhe (peatasid auto, järelikult tahtsid midagi küsida), mida rõhutab oletamist väljendav adverb vist. Nagu episteemilistes tingimuslauseteski (vt Dancygier 2006: 87-88; Plado 2008: 127), nii ei saa ka episteemilistes otstarbelauseis esineda konditsionaalne verbivorm. Tõenäoliselt on see põhjustatud sellest, et episteemilises otstarbelauses esineb sündmus, mille toimumine on kõnehetkeks teada, ning seega kaob vajadus sündmuse hüpoteetilisust markeeriva verbivormi järele.

(17’) Sa vist tahtsid midagi küsida, et auto peatasid.

Konversatsioonilistest otstarbelausetest esineb nii kõneakti- kui ka metakeelelisi otstarbelauseid. Kõneaktiotstarbelause (näide 18) põhjendab, miks koolonile järgnev väide edastatakse ning seda saab parafraseerida sisutasandi otstarbelausega (näide 18'). Metakeeleline otstarbelause kommenteerib mõnd pealauses kasutatud sõna, lauses 19 kommenteeritakse kõrvallausega pealause sõna mahe: vastuvõtja saab teada, et jutu hakatus oli isegi veidi leebem kui mahe, maheda asemel võiks peaaegu kasutada isegi sõna südamlik.

(18) Et oleks selge sott: siin lauas istuvad mehed, kes suudavad veel õlut juua. (ILU1990)

(18') Et oleks selge sott, siis väidan, et siin lauas istuvad mehed, kes suudavad veel õlut juua.

(19) Õues oli kevad, ka jutu hakatus oli mahe, et mitte öelda südamlik. (ILU1990)

\section{Verbivorm otstarbelausetes}

\subsection{Infiniitsus vs. balansseeritus ja madaldamine}

Otstarbelausetes mängib olulist rolli predikaatverbi vorm. Eesti keele otstarbelauses võib predikaat olla kas konditsionaalis või $d a$-infinitiivis (EKG II: 310; Rannut 1981: 73), nii et predikaat võib olla nii finiitne kui ka infiniitne verbivorm. Et tüpoloogias on sageli keeruline määrata, kas verbivorm on finiitne või infiniitne, on loobutud sellisest morfoloogilisest määratlusest ning otstarbelausetes esinevaid predikaatverbe jagatakse verbivormide kasutusvõimaluste järgi kas balansseeritud või madaldatud (ingl balanced; deranked) verbivormideks.

Nimetatud terminid võttis kasutusse Leon Stassen (1985: 76-83), kes rääkis kahe kindlas ajalises järgnevuses oleva sündmuse sidumisel balansseeritud ja madaldatud strateegiast. Balansseeritud strateegia korral on mõlema sündmuse predikaadid struktuuri poolest samal tasandil, nt rindlause Mart vaatas aknast välja ja märkas tänaval võorrast punast autot ning ka temporaaladverbiaallausega põimlause Kui Mart aknast välja vaatas, märkas ta tänaval võõrast punast autot. Mõlema sündmuse predikaat on indikatiivne ning seega on mõlemal juhul tegemist balansseeritud strateegiaga. Oluline 
on, et balansseeritud strateegia korral kasutatakse verbivormi, mis saab esineda iseseisvas lauses. Seevastu madaldatud strateegia korral jääb vaid üht sündmust väljendav verb finiitseks ning teine markeeritakse kui alistatu, nt põimlauses Laps jooksis õue, et näha ema tulekut on otstarbelause verb da-infinitiivi vormis ning sekundaartarindiga lauses Aknast välja vaadates märkas Mart tänaval võõrast punast autot on madaldatud sündmuse verb des-vormis. Madaldatud verbivorm ei saa esineda iseseisvas väitlauses.

Sonia Cristofaro (2003: 57) peab seda, kas verbivormi saab kasutada iseseisvas väitlauses, veelgi olulisemaks; juba see, et verbivorm ei saa esineda iseseisvas väitlauses, on piisav tingimus, et käsitleda seda madaldatuna; seejuures ei ole tähtis, kas ja kuidas verbivormi madaldatus struktuuris väljendub.

Eesti keele otstarbelause predikaadina esinev $d a$-infinitiiv on seega selgelt madaldatud verbivorm, sest kuigi see võib esineda kõrvallause ning käsk- ja küsilause öeldisena, ei saa $d a$-infinitiiv olla iseseisva väitlause predikaadiks. Olukord on aga keerulisem konditsionaalse öeldisverbiga otstarbelausete puhul. Kuigi üldiselt konditsionaal iseseisva väitlause predikaadi vormiks olla ei saa, võib seda siiski kasutada juhul, kui konditsionaali abil pehmendatakse väljendusviisi kategoorilisust, taotletakse ettevaatlikkust või viisakust (näide 20) (EKG II: 34-35). Samas on väidetud, et sääraste lausete puhul on võimalik juurde mõelda tingimus (lause 20 puhul näiteks kui teile vähegi sobib). Seega võib konditsionaali pidada pigem madaldatud verbivormiks. ${ }^{4}$

(20) Ma ootaksin veel veidi.

Kui pidada eesti keele konditsionaali madaldatud verbivormiks, siis erineb eesti keel otstarbelausete poolest saksa ja soome keelest, kus otstarbelause öeldisverb võib olla nii madaldatud kui ka balansseeritud (Cristofaro 2005: 508-509). Saksa keeles võib otstarbelause predikaat olla kas indikatiivi, konjunktiivi või infinitiivi vormis (Heidolph jt 1984: 85) ja soome keeles kas konditsionaalis või indikatiivis (ISK: 1079).

Eesti keelel on sarnane mall vene ning läti keelega, kus otstarbelause predikaat võib olla samuti kas infinitiivis või konditsionaalis (Dibrovoi 2001: 545546; Fennell, Gelsen 1980: 188, 267). ${ }^{5}$ Siiski on läti keeles infinitiiv otstarbelause predikaadi vormina piiratum kui eesti keeles: infinitiivi saab kasutada vaid juhul, kui pealauses on liikumisverb; muudel juhtudel tuleks kasutada konditsionaali (Fennell, Gelsen 1980: 189, 267), s.t infinitiiv seostub vaid nende otstarbelausetega, mida Cristofaro (2003: 157) on pidanud tüpoloogiliselt tüüpilisimaiks. Et veel XVII sajandil ei ole eesti keeles olnud $d a$-infinitiivis öeldisverbiga otstarbelauseid (Penjam 2008), võib arvata, et see mall on eesti keeles kodunenud hiljem kas vene või saksa keele toel.

Järgnevalt tutvustan lähemalt eesti keele otstarbelausetes esinevaid ja esinenud verbivorme ning vaatan, millal kasutatakse $d a$-infinitiivis ja millal konditsionaalis predikaadiga otstarbelauseid.

${ }^{4}$ Helle Metslang (1999) eristab konditsionaali kaht interpretatsiooni: raamitõlgendus ja intentsioonitõlgendus. Raamitõlgenduse puhul alati ning enamasti ka intentsioonitõlgenduse puhul kasutatakse konditsionaali madaldatud verbivormina. Intentsioonitõlgenduse saab konditsionaal aga ka näitelause 20 tüüpi lausetes.

${ }^{5}$ Cristofaro (2005: 506) on aga pidanud vene keelt nende keelte hulka kuuluvaks, kus võib otstarbelauses kasutada nii balansseeritud kui ka madaldatud verbivormi. 


\subsection{Eesti keele $d a$-infinitiivse ja konditsionaalse predikaadiga otstarbelaused}

Kui tänapäeval võib tinglikult öelda, et eesti keele otstarbelausete öeldisverbiks saab olla vaid madaldatud verbivorm (kas $d a$-infinitiivis või konditsionaalis), siis varem on eesti keele otstarbelauses võinud esineda ka balansseeritud verbivorm. Wiedemanni „Eesti keele grammatika” ([1875] 2011: 710) väitel on lisaks $d a$-infinitiivile ja konditsionaalile otstarbelause öeldisverbi vormina kasutatud ka indikatiivi (läheme linna, et ma seal saan kuulda). 1990. aastate kirjakeele korpuses leiduvate sisutasandi otstarbelausete hulgast oli $d a$-infinitiivse öeldisverbiga lauseid 975 ehk $67,3 \%$ ning konditsionaalse öeldisverbiga lauseid 469 ehk 32,4\%. Lisaks oli kolm indikatiivse öeldisverbiga lauset, millest üks kandis selgelt arhailisuse pitserit, ning üks lause, kus sidendit kordamata oli rinnastatud $d a$-infinitiivse ja konditsionaalse predikaadiga otstarbelause.

Varasemates käsitlustes (Rannut 1981: 73-74; EKG II: 310) on eesti keele konditsionaalse ja $d a$-infinitiivse öeldisverbiga otstarbelausete peamise erinevusena esile toodud see, et $d a$-infinitiivi saab kõrvallause predikaadi vormina kasutada vaid siis, kui pea- ja kõrvallause tegevussubjektid on identsed. Korpusest leitud otstarbelausete põhjal pean aga siin nende kahe otstarbelause peamiseks erinevuseks hoopis referentsiaalset sõltumist pealausest. $d a$ infinitiivse öeldisverbiga otstarbelause on pealausest referentsiaalselt sõltuv, mis avaldub selles, et pealause moodustajad saavad kontrollida $d a$-infinitiivse öeldisverbiga otstarbelause grammatilise subjekti kustutust. ${ }^{6}$ Seevastu konditsionaalse öeldisverbiga otstarbelause on pealausest referentsiaalselt sõltumatu kõrvallause. Järgnevalt vaatan, millised need moodustajad on, mis otstarbelause subjekti väljajättu kontrollivad.

5.2.1. $d a$-infinitiivse öeldisverbiga otstarbelaused. $d a$-infinitiivse öeldisverbiga otstarbelausete hulgas on eri tüüpide jaotumus suhteliselt sarnane kõikide otstarbelausete jaotumusega: enim on I tüüpi kõrvallauseid (617 ehk 63,3\%), ligi kolmandiku moodustavad aga II tüüpi otstarbelaused (306 ehk $31,4 \%$ ), vähim on III tüüpi kõrvallauseid (52 ehk 5,3\%). Olulisena tuleb siin esile tõsta seda, et kõikides korpuses leiduvates III tüüpi otstarbelausetes on kasutatud $d a$-infinitiivset öeldisverbi.

Otstarbelause $d a$-infinitiivse öeldisverbi korral ei selgu tegevuse sooritaja mitte kõrvallausest, vaid referentsiaalse seose kaudu pealausest. Järgnevalt toon välja need kõrvallause subjekti väljajätu kontrollijad, mis uuritavast keelematerjalist esile tulid.

1. Kõige sagedamini kontrollib pealausega samaviitelise otstarbelause subjekti väljajättu pealausega edasi antud sündmuse või olukorra kõige aktiivsem osaline (ehk pealause tegevussubjekt). Näiteks lause 21 pealause subjekt ja ühtlasi ka agent on samas ka kõrvallause agendiks, s.t pealause subjekt Maria on see, kes on otstarbelause tegevuse sooritaja.

(21) Maria paneb end riidesse, et õue minna. (ILU1990)

Samas ei pruugi pealause kõige aktiivsem osaline olla ei grammatiline subjekt ega semantilise rolli poolest ka mitte agent. Näiteks lause 22 pealause

${ }^{6}$ Mitte aga tegevussubjekti kustutust, nagu ütleb EKG II (310). 
tegevussubjektiks on hoopis omaja, kes on lauses vormistatud adverbiaalina, kuid kes siiski kontrollib osalauses kirjeldatut ning on kõrvallause plaanitava tegevuse sooritajaks; lauses 23 aga kontrollib otstarbelause subjekti väljajättu tegevussubjekt, mis on vormistatud genitiivatribuudina.

(22) Aga Magnusel polnud mingit topsikut ühes, et vett välja loopida. (ILU1990)

(23) Sellel laupäeval... toimub Toris järjekordne eesti sõjameeste kokkutulek. Et mälestada langenud sõjakaaslasi, anda teatepulk üle tänastele riigikaitsjatele ja asutada riigikaitsefond Lembitu ... (AJA1990)

Sarnaselt on Ellen Uuspõld (1972: 113-115) näidanud ka des-konstruktsiooni agenti kirjeldades, et selleks ei pea alati olema mitte põhilause grammatiline subjekt, vaid võib olla ka adessiivis agentadverbiaal, genitiivatribuut või põhilause öeldisverbi rektsioonistruktuuri kuuluv laiend.

Lisaks esineb lauseid (näited 24, 25, 26), kus nii pea- kui ka kõrvallause tegijat ei ole täpsustatud (pealause tegija on näiteks peidetud $d a$-infinitiivse, impersonaalse või isikulõpuga markeerimata konditsionaalis predikaadi abil), kuid on ikkagi selge, et pea- ja kõrvallause tegija on üks ja seesama.

(24) Kust võtta valuutat, et masinatele kütust osta? (AJA1990)

(25) Kas selleks koolis käiakse, et üksteiselt lollusi õppida? (ILU1990)

(26) Et vastata, tuleks teada, millal stabiilsus kadus: see toimus aastail 1939_ 1940. (AJA1990)

Kuigi üldjuhul kontrollib otstarbelause subjekti väljajättu pealause kõige aktiivsem osaleja (s.t otstarbelause väljajäetud subjekt on samaviiteline pealause tegevussubjektiga), on 1990. aastate korpuses esinevate lausete hulgas siiski 42 lauset (ehk 4,3\% da-infinitiivse öeldisverbiga lauseist), kus otstarbelause subjekti väljajättu kontrollib pealause mõni muu osaline. Järgnevad rühmad kirjeldavadki neid juhte (see ei pruugi nii väikese lausete arvu tõttu olla ammendav loend võimalikest subjekti väljajätu kontrollijaist).

2. Kõrvallause subjekti väljajättu võib kontrollida pealause osaline, mis semantilise rolli poolest vastab kasusaajale. ${ }^{7}$ Siin rühmas võib eristada kaht konstruktsiooni.

1. Konstruktsioon, kus pealause öeldisverbiks on kolmevalentne verb (näited 27, 28). Lauses 27 võivad surma saada Leedu presidendi mehed, mitte aga president ise, ning lauses 28 peab järgmise aasta kütteperioodiks ette tootma kombinaat, kellele laenu antakse, mitte aga laenuandja.

(27) Leedu president... ei olnud taganud oma meestele head ettevalmistust ja piisavat kaitset, et mitte surma saada. (AJA1990)

(28) Seega oleks mõtekas anda kombinaadile laenu, et toota ette järgmise aasta kütteperioodiks. (ILU1990)

2. Sellise kasusaajaga ${ }^{8}$ konstruktsioon, kellele midagi näib või tundub. Näiteks kuuluvad siia laused, kus midagi on kellegi meelest/jaoks millekski

\footnotetext{
${ }^{7}$ Siin ei eristata kasu- ega kahjusaajat.

${ }^{8}$ Selle osalise puhul on tegemist rolliga, millel on nii kasusaajale kui ka kogejale omaseid jooni. Nimetan seda osalist siin tinglikult kasusaajaks.
} 
palju, vähe, piisavalt jmt. See rühm on ülekaalukalt suurim, sisaldades 33 lauset 42-st. Kuigi pealause osaline, kes kõrvallause subjekti väljajättu kontrollib, võib olla nii eksplitsiitne kui ka implitsiitne, näib olevat tavalisem, et kasusaaja selgub kas kontekstist või hoopis järeldatakse kõneleja ning vastuvõtja ühiste maailmateadmiste põhjal, näiteks on lauses 29 implitsiitseks kasusaajaks kõneleja. Korpuses esinenud lausetest vaid kuues oli kõrvallause subjekti väljajättu kontrolliv kasusaaja eksplitsiitselt esitatud (näide 30).

(29) Sa oled selleks liiga ohtlik mänguasi, et sinuga kauem mängida! (ILU1990)

(30) See on heliloojale küllalt pikk aeg, et proovida ennast eri suundades... (AJA1990)

Kuigi sellistes lausetes võib kasusaaja kõrvallause subjekti väljajättu kontrollida, on peamiseks kontrollijaks siiski pealause tegevussubjekt, vrd lauseid 31 ja 31' ning 32 ja 32'. Lauses 31 ei ole kõrvallause subjekti kustutuse kontrollijaks mitte pealause hinnanguandja, vaid tegevussubjekt, s.t see, kes maailmas kõlapinda ei leia, ei ole mitte see, kelle jaoks Vicente Aleixandre liiga eksklusiivne tundub, vaid Vicente Aleixandre ise; lauses 31' aga on kõrvallause kustutatud subjekt samaviiteline pealause kasusaajaga, s.t see, kes Vicente Aleixandret oma lemmikluuletajaks pidada ei saa, on sama, kellele ta liiga eksklusiivne tundub.

(31) Vicente Aleixandre... tundub jälle liiga eksklusiivne, et maailmas laiemat kõlapinda leida. (AJA1990)

(31') Vicente Aleixandre... tundub jälle liiga eksklusiivne, et teda oma lemmikluuletajaks pidada.

(32) Seega oleks mõtekas anda kombinaadile laenu, et toota ette järgmise aasta kütteperioodiks. (ILU1990)

(32') Seega oleks mõttekas anda kombinaadile laenu, et tagada ka edasine tootmine.

3. Lausetes, kus pealauses on kasutatud impersonaali, võib lisaks pealause tegevussubjektile (näide 33') otstarbelause subjekti väljajättu kontrollida ka predikaatverbi täisobjekt. Vrd näiteks lauseid 33, 33' ja 33”. Kui lauses 33 on otstarbelause kustutatud subjektiks pealause tegevusobjekt ehk kohtunikud, siis lauses 33' kontrollib kõrvallause subjekti väljajättu pealause tegevussubjekt. Kui aga pealause öeldisverb muuta isikuliseks ning lisada pealausesse tegija, nagu lause 33" puhul, siis muutub ühtlasi pealause tegija ka kõrvallause kustutatud subjektiks, s.t lause 33" puhul on otstarbelause tegijaks 1. isik. Eesti keeles saab impersonaali täisobjekt kui ainuke argument mõningaid subjekti omadusi, nimelt on see nominatiivis ning mineviku liitaegades võib öeldisverb ühilduda sellega arvus (EKK: 365). Lisaks väidetakse EKK-s, et impersonaali täisobjekt seisab harilikult lause alguses nagu aluski, kuid Maili Nurme (2012) on näidanud, et see väide ei vasta tõele. Kuigi võime kontrollida otstarbelause subjekti väljajättu ei ole eesti keeles vaid grammatilise subjekti omadus, on siiski tüüpiline $d a$-infinitiivse öeldisverbiga otstarbelause subjekti kustutuse kontrollija pealause tegevussubjekt ja kõige tüüpilisemaks tegevussubjektiks on grammatiline subjekt, mistõttu saab ka impersonaalse öeldisverbi täisobjekti võimet vaatlusalust kustutust kontrollida pidada veel üheks omaduseks, mis impersonaalset täisobjekti subjektile lähendab. 
(33) Nimelt juhatati kõrgestiaustatud kohtunikud otse lava taha, kuhu piletiga iluimetlejail asja ei olnud. Eks ikka selleks, et tulevasi misse oma silmaga ja ligidalt näha. (AJA1990)

(33') Kohtunikud juhatati lava taha, et neile võistluse reegleid selgitada.

(33") Nimelt juhatasin kõrgestiaustatud kohtunikud otse lava taha, et tulevasi misse oma silmaga ja ligidalt näha.

Kuigi 1990. aastate korpuse otstarbelauseid sisaldavate põimlausete hulgas on nii vähe impersonaalse öeldisverbiga lauseid, et nende põhjal pole võimalik teha järeldusi selle kohta, kas täisobjekt saab otstarbelause subjektiks olla vaid juhul, kui pealause täisobjekt on eluline, näib siiski, et sinnapoole asi kaldub. Nt lauses 34 on kõrvallause subjekt sama kui pealause tegija ehk see, kes auto hooldusesse viib, mitte aga auto ise.

(34) Auto viidi hooldusse, et edaspidi väiksema kütusekuluga sõita.

$d a$-infinitiivse öeldisverbiga otstarbelause subjekti väljajättu kontrollib niisiis peamiselt pealause tegevussubjekt. Kahes konstruktsioonis - kasusaajaga ning impersonaalses täisobjektiga konstruktsioonis - võib kõrvallause subjekti väljajättu kontrollida ka tegevusobjekt (vastavalt pealause kasusaaja ja täisobjekt). Siiski on ka nendel juhtudel teiseks võimalikuks kõrvallause subjekti väljajätu kontrollijaks pealause tegevussubjekt.

5.2.2. $d a$-infinitiiv geneerilise situatsiooni väljendajana. Et infinitiivil ei ole eksplitsiitset subjekti- ega ajamarkeeringut, sobib see geneerilisuse edasiandmiseks (Plado 2010: 267). Näiteks $d a$-infinitiivse öeldisverbiga (sisuliste) konditsionaallausete puhul muudab $d a$-infinitiivi kasutamine lause enamasti geneeriliseks, s.t lause ei kirjelda mitte konkreetset sündmust ega objekti, vaid üldist situatsiooni ning välistab viite konkreetsele ajahetkele (Plado 2010: 266-268), mistõttu kasutatakse geneerilisi lauseid sageli juhiste andmises ja üldiste seaduspärasuste kirjeldamisel (Dahl 1975: 99-100). Kuid kas geneerilisust saab edasi anda ka da-infinitiivis öeldisverbiga otstarbelausega, mille oluliseks erinevuseks tingimuslausest on see, et otstarbelause on pealausest referentsiaalselt sõltuv ning seega on olemas viide subjektile? Kas geneerilisust saab väljendada $d a$-infinitiivis öeldisverbiga otstarbelause korral üksnes siis, kui pealausest ega lause lähikontekstist ei selgu lause aktiivseim osaleja?

1990. aastate $d a$-infinitiivis öeldisverbiga otstarbelausete hulgas, mille tegevussubjekt kattub pealause tegevussubjektiga, leidsin vaid 48 lauset, kus tegevussubjekti ei olnud eksplitsiitselt väljendatud ei analüüsitavas lauses ega ka mitte selle lähiümbruses. ${ }^{9}$ Lausa 30 lauset saab tõlgenduse, et taustal on geneeriline tegija. Näiteks lause 35 abil edasi antu kehtib igal ajahetkel ükskõik kelle kohta.

(35) Et universaalset palderjanijuurt sügisel ära tunda, tuleks palderjan tuua koduaeda... (AJA1990)

Suhteliselt sage (13 korral) oli ka tõlgendus, et tegijaks on 1. isik. Lausega 36 põhjendab kõneleja järgneva Tiibeti legendi jutustamist ja ühtlasi juhatab selle sisse, s.t seletab oma järgmist tegevust.

${ }^{9}$ Laused, kus pealause öeldisverb on impersonaalne, jätsin siin vaatluse alt välja. 
(36) Et vastata küsimusele, mis seos on sellel kõigel ahvist ülestõusmisega, tuleb alustada vanast Tiibeti legendist. (ILU1990)

Lisaks on kaks lauset, kus peidetud tegijaks on 2. isik [ühel juhul oli tegemist vestluspartnerile suunatud küsimusega (näide 37) ning teisel juhul vestluspartnerile antavate juhtnööridega] ning kolm lauset, kus ka kontekstist ei selgu, kas silmas on peetud geneerilist tegijat või 1 . isikut, nt lause 38 , kus kõneleja räägib küll iseendast, kuid samas loob ta laiema tausta, mis peaks kehtima kõigi treenerite kohta).

(37) Selleks, et rahvas nendeks etendusteks saali saada, on vaja kõvasti vaeva näha? (AJA1990)

(38) Pealegi tuleb treenerina ju ikka katsetada, et oma mängijamaterjalist parimat kätte saada... (AJA1990)

Seega võib öelda, et kuigi üldiselt ei too $d a$-infinitiivis öeldisverbi kasutamine otstarbelauses kaasa geneerilisuse tõlgendust, sest erinevalt tingimuslausetest on otstarbelause tegevussubjekt teada (üldjuhul sama kui pealause tegevussubjekt), muutub see siiski peamiseks tõlgenduseks juhul, kui tegevussubjekt ei selgu ei pealausest ega ka mitte lähikontekstist. Samas ei ole geneerilisuse tõlgendus sellistegi lausete puhul ainuvõimalik - olulisena tõusevad esile ka tõlgendused, kus taustal olevaks tegijaks on 1 . isik või suhtluspartnerile suunatud kõneaktide korral ka 2. isik.

5.2.3. Konditsionaalse öeldisverbiga otstarbelaused. Konditsionaalse öeldisverbiga otstarbelausete hulgas järgnevustüüpi ei esinenud, põhitüüpi otstarbelauseid oli 320 ehk 68,2 \% ning sobivus- ja kvantumitüüpi 149 ehk $31,8 \%$.

Konditsionaalse öeldisverbiga otstarbelause on pealausest referentsiaalselt sõltumatu, s.t kõrvallause subjekti referent ei pea kattuma mõne pealause osalisega. Ka Lehte Rannut (1981: 73) väidab, et kui pea- ja kõrvallause tegevuse sooritaja on sama isik, võib otstarbelause öeldisverb olla nii $d a$-infinitiivis kui ka konditsionaalis. Siiski selgub korpusest, et konditsionaali kasutatakse peamiselt siis, kui kõrvallause subjekt ei kattu pealause tegevussubjektiga. Lausa 435 lauses (92,8 \% lausetest) ei kattu kõrvallause subjekt pealause tegevussubjektiga, kattub vaid 33 lauses (7,0 \% lausetest); lisaks on üks lause, kust ei selgu, kas kõrvallause subjekt on sama kui pealause tegevussubjekt või mitte.

Kui kõrvallause subjekt kattub pealause tegevussubjektiga, valitakse öeldisverbi vormiks konditsionaal siis, kui kõrvallause predikaadiks on modaalverb (korpuses 17 lauset). Et modaalverbid esinevad koos täistähendusliku verbi infiniitse vormiga, siis kasutatakse konditsionaali tõenäoliselt selleks, et vältida samas osalauses kahe infinitiivse verbivormi esinemist ning seega mitte muuta lause sisu raskesti mõistetavaks (vrd lauseid 39 ja 39').

(39) Eestlased said seal neljapäevaöösiti kokku kuradiga ja andsid talle kolm tilka verd, et saaks elustada krati. (ILU1990)

(39') Eestlased said seal neljapäevaöösiti kokku kuradiga ja andsid talle kolm tilka verd, et saada elustada kratt. 
Siiski esineb umbes samal hulgal lauseid (16 lauset), kus võiks samaväärselt kasutada konditsionaali asemel ka $d a$-infinitiivi, nt vrd lauseid 40 ja 40'.

(40) Mind huvitas ainult kellaaeg, et ma juuksuritooli ei hilineks. (ILU1990)

(40') Mind huvitas ainult kellaaeg, et juuksuritooli mitte hilineda.

\section{Kokkuvõte}

Otstarbelauset seostatakse tüüpiliselt tahtliku tegevusega. Ka korpuse materjalist selgus, et lausa 2/3 otstarbelauseist on seotud pealause tahtliku tegevuse või seisundiga. Eesti keele grammatikas nimetatud kahele otstarbelause tüübile (millest esimene väljendab tahtliku tegevuse taotletavat tagajärge ja teine funktsiooni, mille täitmiseks on keegi või miski vajalik/mittevajalik või sobiv/sobimatu) lisandus ka kolmas, kus otstarbelausekujulise kõrvallausega antakse edasi kas peidetud otstarvet või pigem tagajärge ja ajalist järgnevust.

Eesti keele otstarbelause on nii sisu kui ka vormi poolest tihedalt seotud komplement-, põhjus- ja tagajärjelausega.

Olulisena tõuseb esile otstarbelausete öeldisverbi vorm, mis valitakse vastavalt sellele, kas tegemist on pealausest referentsiaalselt sõltuva või sõltumatu kõrvallausega. $d a$-infinitiivse öeldisverbiga otstarbelause on pealausest referentsiaalselt sõltuv, s.t tema subjekti obligatoorset väljajättu kontrollib mõni pealause osaline, milleks kõige sagedamini on pealause tegevussubjekt, aga selleks võib olla ka tegevusobjekt (pealause kasusaaja või impersonaalse pealause korral täisobjekt). Konditsionaalse öeldisverbiga otstarbelause on pealausest referentsiaalselt sõltumatu ning seda saab kasutada nii juhul, kui kõrvallause subjekt on pealause mõne argumendiga sama, kui ka siis, kui kõrvallause subjekt ei kattu ühegi pealause argumendiga. Siiski näib korpuse materjalide põhjal olevat normiks see, et sama tegevussubjekti korral kasutatakse $d a$-infinitiivi. Konditsionaali eelistatakse selgelt vaid juhtudel, kui $d a$ infinitiivi kasutus muudaks lause raskemini mõistetavaks (nt modaalverbide puhul).

Et $d a$-infinitiivis öeldisverbiga otstarbelause tegevussubjekt paistab pealausest, ei muuda $d a$-infinitiivi kasutamine lauset geneeriliseks (nagu nt tingimuslause korral), küll aga võib seda tendentsi märgata juhul, kui ei pealausest ega ka lähikontekstist tegevussubjekti ei selgu. Samal ajal ei ole see nendelgi juhtudel üldine, vaid peidetud tegijaks võib olla ka 1. ning harvemini 2. isik.

\section{Kirjandus}

C r i s t o f a r o, Sonia 2003. Subordination. Oxford: Oxford University Press.

$\mathrm{C}$ r i s t o f a r o, Sonia 2005. Purpose clauses. - The World Atlas of Language Structures. Toim M. Haspelmath, M. S. Dryer, D. Gil, B. Comrie. Oxford: Oxford University Press, lk 506-509.

D a h l, Östen 1975. On generics. - Formal Semantics of Natural Language. Toim E. Keenan. Cambridge: Cambridge University Press, lk 99-111.

D a n c y g i e r, Barbara 2006. Conditionals and Predictions. Time, Knowledge and Causation in Conditional Constructions. Cambridge: Cambridge University Press. 
D a n c y g i e r, Barbara, S w e e t s e r, Eve 2006. Mental Spaces in Grammar: Conditional Constructions. Cambridge: Cambridge University Press.

D i b r ov o i 2001 = Современный русский язык: Теория. Анализ языковых единиц. Часть II: Морфология. Синтаксис. Ред. Е. И. Дибровой. Москва: Академия.

EKG II = Mati Erelt, Reet Kasik, Helle Metslang, Henno Rajandi, Kristiina Ross, Henn Saari, Kaja Tael, Silvi Vare, Eesti keele grammatika II. Süntaks. Lisa: Kiri. Tallinn: Eesti TA Keele ja Kirjanduse Instituut, 1993.

EKK = Mati Erelt, Tiiu Erelt, Kristiina Ross, Eesti keele käsiraamat. Teine, täiendatud trükk. Tallinn: Eesti Keele Sihtasutus, 2000.

E relt, Mati 2004. Märkmeid eesti keele komplekslause kohta. - Keel ja Kirjandus, nr 6, lk 401-413.

Fenne11, Trevor G., Gelsen, Henry 1980. A Grammar of Modern Latvian. Kd 1. The Hague-Paris-New York: Mouton Publishers.

H e i d o l p h, Karl Erich, Flä m i g, Walter, M o t s c h, Wolfgang 1984. Grundzüge einer deutschen Grammatik. Berlin: Akademie-Verlag.

Heine, Bernd, Kuteva, Tania 2002. World Lexicon of Grammaticalization. Cambridge: Cambridge University Press.

H ö g l u n d, Kirsi 2006. Estnisk satsföljd och meningsstruktur.Uppsala: Uppsala Universitet.

ISK = Auli Hakulinen, Maria Vilkuna, Riitta Korhonen, Vesa Koivisto, Tarja Riitta Heinonen, Irja Alho, Iso suomen kielioppi. Helsinki: Suomalaisen Kirjallisuuden Seura, 2004.

I t k o n e n, Esa 2001. Maailman kielten erilaisuus ja samuus. (Yleisen kielitieteen julkaisuja 4.) Turku: Turun Yliopisto.

K a r e l s o n, Rudolf 1959. Sidesõnad läänemeresoome keeltes. Dissertatsioon filoloogiakandidaadi teadusliku kraadi taotlemiseks. Tartu: Tartu Riiklik Ülikool.

M e t $\mathrm{s}$ l a n g, Helle 1999. Is Estonian and Finnish conditional actually a conditional. - Estonian: Typological Studies III. Toim M. Erelt. Tartu: Tartu Ülikool.

N u r m e, Maili 2012. Impersonaali objekt. - Keel ja Kirjandus, nr 5, lk 335-345.

P e nj a m, Pille 2008. Eesti kirjakeele $d a$ - ja $m a$-infinitiiviga konstruktsioonid. (Dissertationes philologiae Estonicae Universitatis Tartuensis 23.) Tartu: Tartu Ülikooli Kirjastus.

P l a d o, Helen 2008. Adverbiaallausete funktsioonipõhine liigitus eesti keele tingimus- ja põhjuslausete näitel. - Emakeele Seltsi aastaraamat 53 (2007). Tallinn: Teaduste Akadeemia Kirjastus, lk 122-145.

Pla d o, Helen 2010. Eesti keele $d a$-infinitiivis öeldisverbiga tingimuslaused. ESUKA - JEFUL, nr 2, lk 255-272.

P l a d o, Helen, L i n d s t r ö m, Liina 2012. Eesti keele mööndlause: markerid ning koht alistuse ja rinnastuse teljel. - Emakeele Seltsi aastaraamat 57 (2011). Tallinn: Teaduste Akadeemia Kirjastus, lk 131-161.

R a n n u t, Lehte 1981. Põimlause eesti keeles. Tallinn: Valgus.

S chmidtke-B ode, Karsten 2009. A Typology of Purpose Clauses. Amsterdam-Philadelphia: John Benjamins.

$\mathrm{S} \mathrm{ch} \mathrm{mid} \mathrm{tk} \mathrm{e} \mathrm{-} \mathrm{B} \mathrm{o} \mathrm{d} \mathrm{e,} \mathrm{Karsten} \mathrm{2010.} \mathrm{The} \mathrm{role} \mathrm{of} \mathrm{benefactives} \mathrm{and} \mathrm{related} \mathrm{notions}$ in the typology of purpose clauses. - Benefactives and Malefactives. Typological Perspectives and Case Studies. Toim F. Zúñiga, S. Kittilä. Amsterdam-Philadelphia: John Benjamins, lk 121-146.

S t a s s e n, Leon 1985. Comparison and Universal Grammar. Oxford: Blackwell. 
S w e e t s e r, Eve E. 1990. From Etymology to Pragmatics. Metaphorical and Cultural Aspects of Semantic Structure. Cambridge: Cambridge University Press.

Th o m p s o n, Sandra A., L o n g a c r e, Robert E. 1985. Adverbial clauses. - Language Typology and Syntactic Fieldwork. Toim T. Shopen. Cambridge: Cambridge University Press, lk 171-234.

U u s p õ ld, Ellen 1972. Agendi väljendamisest des-konstruktsiooniga lausetes. Keel ja struktuur 7. Tartu: Tartu Riiklik Ülikool.

W i e d e m a n n, Ferdinand Johann [1875] 2011. Eesti keele grammatika. Tlk H. Laanekask. Tallinn: Eesti Teaduste Akadeemia Emakeele Selts.

Artikkel on kirjutatud ETF-i grandi 8595 toel.

\section{The Estonian Clause of Purpose}

Keywords: Estonian, adverbial clauses, purpose clauses, conditional mood, $d a$-infinitive as predicate, genericity

The article analyzes Estonian purpose clauses on a typological background. In Estonian, there are three kinds of purpose clauses: (1) clauses expressing the desired result of intentional action, (2) clauses expressing a function for the fulfilment of which somebody or something is necessary/unnecessary or appropriate/inappropriate, and (3) clauses expressing either a hidden purpose or, rather, a consequence and temporal succession.

The Estonian purpose clause is, by form and by content, closely connected with the complement clause as well as with the adverbial clauses of reason and result. Its similarity now with the clause of reason, now with that of result is probably due to its simultaneous expression of both reason and result (the reason as well as the expected result of the action described in the main clause).

A purpose clause with a $d a$-infinitive as main verb is referentially dependent on the main clause. The obligatory omission of its subject is controlled by a member of the main clause, mostly the actor, but possibly also the undergoer (the beneficiary of the main clause or, in the case of an impersonal main clause, the total object). If the purpose clause is in the conditional mood, the clause is referentially independent of the main clause and it can be used regardless of whether its subject coincides with any argument of the main clause or not.

Helen Plado (b. 1981), MA, University of Tartu, Institute of Estonian and General Linguistics, research fellow, helen.plado@ut.ee 